\title{
INCENTIVES TO AIR POLLUTION CONTROL
}

\author{
Paul H. Gerhardt*
}

"Should it be the carrot or the stick?" That is the metaphorical question economists often ask about pollution abatement programs. In the debate which has ensued between economists, legislators, administrators, and businessmen, adversaries have cloaked the substantive issues in a shroud of public rhetoric. It is the purpose of this article to help cut away this shroud, and to lay out the basic policy alternatives available to those who would control air pollution.

\section{I}

\section{What is the ProbLem?}

There is small if any doubt that air pollution can and has caused substantial social and economic losses. Its role is well documented in experiments, tests, and experience gathered from major episodes. Air pollution contributes to the corrosion of metal and stone; it discolors and makes buildings dirty outside and inside; and in general it contributes to the blight of the neighborhood. ${ }^{1}$

Air pollution also damages and destroys plant life--leading to agricultural and aesthetic losses. It places real restrictions on the types of vegetation that may be raised in many areas of the country. In New Jersey, for example, pollution injury to vegetation has been observed in every county and damage has been reported to at least thirty-six commercial crops. ${ }^{2}$ Air pollution may also limit plant growth and production, impair quality, and may even reduce vigor to a degree where plants are predisposed to further losses as from biotic pathogens. ${ }^{3}$

More importantly, air pollution imposes costs in terms of human health. In testimony before the Subcommittee on Air and Water Pollution of the Committee on Public Works of the United States Senate, Dr. William Stewart, Surgeon General of the Public Health Service, unequivocally stated that air pollution is "unquestionably a factor in the development of not one, but many, diseases affecting literally millions of our people."

The sharply rising incidence of lung cancer, emphysema, bronchitis, and asthma

* Chief, Economic and Social Studies Section, Office of Legislative and Public Affairs, National Ccnter for Air Pollution Control, U.S. Public Health Service, Department of Health, Education, and Welfare.

The author is especially indebted to R.J. Anderson, L.B. Barrett, and Allen Krieese for more than just editorial assistance, and to Marion Van Landingham for the latter.

${ }^{1}$ R. RidKeR, Economic Costs of Air Pollution 57, Ir 5 (1967).

${ }^{2}$ Middleton, Air Pollution Threat to Flora and Fauna Doubles Threat to Man, Conservation CatAlyst, December 1967 , at $\mathrm{I}, 3$.

${ }^{3}$ Treshow, Plant Communities Menaced by Polluted Air, id. at 7, 9 .

Hearings on $S_{780}$ (Air Pollution-1967) Before the Subcomm. on Air and Water Pollution of the Senate Comm. on Public Works, 9oth Cong., rst Sess., pt. 3, at 1131 (1967). 
has been associated with air pollution. Epidemiological surveys reveal that death rates from cardiorespiratory diseases in general are noticeably higher in urban than in rural areas, and that rates increase with city size, as does air pollution. ${ }^{5}$

Dr. Dubos observes that whatever its apparent selectivity, any biologically active substance is likely to react with more than one function. Above and beyond the direct toxic effects that occur rapidly and which are easily detected, there are others that develop more slowly and indirectly. ${ }^{6}$

Government cannot eliminate these economic and social costs by cleaning the air stream as it can purify water for public use. The only practical solution is to reduce substantially the uncontrolled disposal of pollutants to the atmosphere. Air pollution control involves political, economic, and social considerations. The economist's contribution to the discussion of the problem is to attempt an evaluation of some alternative ways in which society might restructure the market process to bring about improved air quality and how these alternatives might compare with direct regulation and enforcement approaches.

\section{II}

\section{Why is Air Pollution an Economic Problem?}

The economist sees air pollution as a classic case of an external diseconomy. External diseconomies arise whenever market forces alone are insufficient to make an individual bear the full costs including the social costs that result from his actions. If these costs can somehow be internalized so that the economic unit generating pollution is required to pay for its elimination, then the diseconomy is removed.?

In a profit-motivated economy profits are maximized to the extent that the cost of waste disposal is minimized. Profits are also maximized to the extent that waste is turned into valuable by-products or recovered products. When the value of such products exceeds the costs of producing them, waste reduction, like the practice of honesty, is its own reward. When the costs of waste reduction and disposal are not offset, the costs of disposal are borne by others than the producer of the wastes. The costs are clean-up and disposal costs. Or they are personal, material, and esthetic damages that are suffered in tolerating polluted air, putrid water, and a trash-littered landscape.

The producers of pollution are generally unaware of the total effects of the pollution they produce. No one producer has an incentive to eliminate his pollution entirely; his incentive, commonly, is limited only to the elimination of that part which adversely affects his own operation. The arguments against going farther are that it will cost too much, that prices will have to be increased, that consumers will not

\footnotetext{
${ }^{5}$ R. Dubos, Man Adapting 216 (1965).

${ }^{\circ}$ Id. at 222-23.

'See generally Kneese, Air Pollution-General Background and Some Economic Aspects, in THE Economics of Arr Pollutron 23, 29-30 ( $\mathrm{H}$. Wolozin ed. 1966).
} 
buy it, and that there is no proof that air pollution is damaging anything anyway, so why pick on me.

It can be asserted that, for survival, producers are obligated to provide a product of value. It can be asserted further that, for social efficiency, value includes product safety and minimum social costs. There can be no question that pollution will be reduced if appropriate incentives can be identified and provided which force producers to account for product safety and social costs.

A manufacturer calculating private costs of production will include raw materials, labor, equipment, facilities, overhead, advertising, and taxes. He will annualize costs based on useful life of capital. He may or may not include the costs of disposing of waste gases and dust. A large portion of these by-products of the manufacturing process are still dispersed into the air and justified on the ground that it is an oconomic function of the atmosphere to assimilate such wastes.

If there are only a few stacks, only a few automobiles, and a limited number of heating units sending pollutants into the air over a community, and if atmospheric conditions are such that these pollutants are soon gone with the wind, the disposal of wastes to the atmosphere may seem efficient. But, if there are many stacks, many automobiles, and thousands of heating units within a limited geographic area all contributing their respective wastes to the surrounding pool of air, the resulting pollution may not be assimilated and costs will be imposed on society.

III

\section{Possible ECONOMIC INCENTIVES}

It should be obvious that internalizing costs does not necessarily mean that producers must bear the total burden. Since the public benefits from both clean air and a productive industrial sector, it is reasonable to expect that the public will pay something for the control of pollution. The question is how.

Examination of alternatives suggests that there are basically two types of incentives that may be used to encourage polluters to reduce or eliminate the emission of pollutants into the atmosphere: economic incentives and enforcement of regulationsthe carrot and the stick.

The economic incentives involve the public's sharing the costs of control in a rather direct way. One simple form of economic incentive would take the form of tax credits and fast write-offs for the initial purchase and installation of control equipment. Other forms of economic incentive would include award payments, emission charges, or combinations of payments and charges. These might be useful in stimulating reduction of emissions over the long run. Award payments might be geared to a percentage reduction from total potential emissions, to an absolute reduction in terms of certain amounts of pollutants, or to the attainment of an emission standard set by a government regulation. 
With a system of emission charges, a company might pay a low charge if the damage caused by its emissions were low, and a high charge if the damages were high. There would be nothing except the economic motivation provided by the incentive scheme to force control of emissions.

In a system combining award payments and emission charges, companies exceeding emission standards might receive payments to offset the cost of control and to keep them from relaxing to the required levels. Companies emitting large amounts of pollution might be charged as an incentive for them to approach the standards. Charges could be geared so that it would be noticeably cheaper for polluters to meet emission standards than to pay emission fees. Charges could conceivably be structured to pay the costs of awards.

The principal alternative to using financial or economic incentives to change the behavior of a polluter would be for a government to enact legislation requiring that certain emission standards be met. Failure to comply could entail the payment of a comparatively steep fine for each day a company is in violation of standards.

A. The Provision of Incentives Through Equipment Tax Credits

Equipment tax credits might appear to be the most attractive economic incentive from the viewpoint of industry. This is a tentative conclusion based on the fact that some forty-odd bills have been brought before Congress which would provide tax credits, rapid write-offs, or both, for the purchase and installation of air pollution control equipment.

A typical bill would offer a twenty per cent tax credit for capital investment instead of the seven per cent credit now allowed for new facilities and equipment. It would also offer a write-off for depreciation purposes of from one to five years instead of the standard useful life basis, which could be twenty years or more. If enacted, such legislation could provide a benefit to industry of roughly $\$ 300,000$ to $\$ 400,000$ above present rates for cvery $\$$ million it spends on the purchase and installation of air pollution control equipment.

It has been estimated that, under the present seven per cent investment tax credit, perhaps \$10 to $\$ 25$ million of assistance is given each year to manufacturing firms investing in air and water abatement equipment combined. Air and water pollution control equipment is also included under the accelerated depreciation allowance for capital equipment-such as double declining balance and sum-of-the-years-digits. The effect is roughly similar to an interest-free loan for the amounts involved. The current annual subsidy through this provision may be $\$ 15-30$ million. ${ }^{8}$

There are a number of possible problems associated with tax credits and rapid write-offs as an incentive to air pollution abatement. In the first place, it may be difficult from a practical administrative standpoint to determine how much of a

\footnotetext{
${ }^{8}$ Working Commttee on Economic Incentrves, Federal Coordinating Committee on the Economic Impact of Poliution Abatement, Cost Sharing with Industry? 6 ( 1967 ) [hercinafter cited as Federal, Coordinating Committee].
} 
plant's investment should be charged to pollution control and how much to process changes undertaken primarily for increased productivity that incidentally may affect a significant reduction in the production of air pollutants. If pollution control means buying a specific piece of equipment, such as an electric precipitator, and installing it to trap escaping and valueless pollutants, then it is comparatively easy to assign costs. But when pollution control is not limited to such simple, end-ofthe-line devices, the assignment of costs is considerably more complicated and would depend heavily on engineering and economic judgments.

The problem is further complicated when air pollution control produces valuable by-products. A producer of carbon black, for example, uses a highly sophisticated filtration system to prevent the loss of a product worth several cents per pound.

A recent issue of Mill and Factory magazine cited other examples which illustrate the importance, for any economic incentive scheme, of relating incentives to net costs.

A steel company has developed a smoke-cleaning process which traps most of the iron dust particles and, after putting them through a sintering process, recharges them for use in its open hearths.

A chemical company has a plant with a dust collection system that accumulates about 4000 tons of fly ash a year. This "waste" material contains about $70 \%$ carbon, and its re-use as fuel brings the company substantial savings. Another plant of this same company used to emit foul smelling benzothiazole. Control equipment costing $\$ 85,000$ was installed and now the company recovers about $\$ 50,000$ worth of benzothiazole a year.

A chlorine user with air pollution controls is now recovering "waste" chlorine that had formerly cost him $\$ 60$ a liquid ton. The recovery costs are now down to only \$19 a ton. ${ }^{9}$

A second difficulty involves the possibility that a policy of tax credits for capital expenditures would encourage industry to commit resources to control hardware approaches instead of looking for possibly lower cost approaches. If this were the result, equipment tax credits would be an inefficient subsidy from an economic point of view.

This bias was succinctly stated by the Working Committee on Economic Incentives of the Federal Coordinating Committee on the Economic Impact of Pollution Abatement in its recent report: ${ }^{10}$

The subsidy is in a small part illusory because the assistance would be given for a higher level of expenditures caused by the subsidy creating an incentive to overuse of capital to the neglect of operating and maintenance expenditures. This would arise because capital costs are made artificially cheaper by virtue of a tax write-off. Tax write-offs are handicapped because they are incapable of providing assistance to all of the costs of abatement. The capital cost accounts for roughly one-third of the total cost for water pollution abatement and one-eighth for air

\footnotetext{
- The Case for Clean Air-A Special Report, MILI \& FActory, April 1967, at 41, 56.

10 Federar Coordinating Committee 27.
} 
pollution abatement. Of course, with subsidies given to capital alone, the capital cost proportion will tend to rise and unnecessarily consume more resources. The addition of chemicals or supervisory personnel often times is less costly than building additional capacity in order to treat larger waste loads. Fuel substitution alone is estimated to be the least-cost alternative in over 60 percent of the cases involving air pollution abatement.

Fuel substitution may be a particularly practical approach to the reduction of sulfur oxide emissions for many coal burning power plants. They may switch from high-sulfur to low-sulfur content coal, to low-sulfur residual oil, to natural gas, to desulfurized coal or fuel oil or to atomic energy-usually at somewhat increased costs. The technology for desulfurization of fuel oil already exists and continuing research and development continues to make such approaches appear increasingly economical. A comprehensive economic incentive system would not discourage such approaches.

In addition to prejudicing polluters in favor of control equipment instead of seeking lower cost alternatives, tax credits and fast write-offs would crec "e additional loopholes in tax laws, which, some would hold, are already riddled by : scial exceptions. Every time aid takes such form, it tends to become a precedent fur still more such programs.

Another argument against tax credits and other financial type incentives is the belief that the costs of pollution control will probably be low and incentives will not really be necessary. It is currently estimated, for example, that for a number of existing industries (including steel, utilities, foundries, petroleum refining, kraft paper, cement, and chemicals) when capital costs are annualized on a ten-year life, including an imputed ten per cent interest, the full additional cost of particulate control will be roughly one-half of one per cent of value added by manufacture. It would appear that such a relatively low cost could be successfully absorbed by most sections of industry.

Some assistance is already available for hardship cases. The Small Business Administration (SBA) has authority to make loans to approximately ninety-five per cent of all non-farm industry in the United States. A small business is defined as a company which is independently owned and operated and is not dominant in its field. Among manufacturing industries facing the greatest abatement costs-foods, paper, chemical, petroleum refining, and primary metals-over ninety per cent are eligible. Under the Small Business Act of $195^{8}$, SBA can make direct loans either by itself or in participation with banks and can guarantee loans made by banks. ${ }^{11}$ Direct loans may be up to $\$ 100,000, \$ 150,000$ for SBA participation loans, and $\$ 350,000$ on guaranteed portion of loans made by private banks. Interest is set at five and one-half per cent on SBA funds and up to eight per cent on bank funds. The maximum term is ten years except for that part of the loan used for facilities construction, which may run up to fifteen years. ${ }^{12}$

\footnotetext{
${ }^{11}{ }_{15}$ U.S.C. $\$ 636(a)(1964)$.

18 Federal Coordinating Commttee 31.
} 
Economic Development Administration (EDA) assistance (financial and technical) can be offered any company, regardless of size, "if pollution abatement actions should 'tend to limit modernization, expansion or solvency of the facility.' Usually such a plant must be in a county which is designated as a 'depressed area.' Nearly one-third of the land area in the United States is currently designated as depressed."1s

Even in areas

outside of "depressed areas," EDA can pay all the cost of technical studies for the purpose of identifying least-cost methods of abating pollution for plants in towns or sections of cities threatened by reduced economic activity. The only condition is that the pollution abatement actions against the affected plant can potentially or actually cause an increase in unemployment. Such a broad mandate allows adequate latitude for assisting any hardship plant which is otherwise economically viable except for the short-term burden of pollution abatement expenditures. ${ }^{14}$

If some kind of additional tax incentive system were to be insisted upon, a somewhat flexible scheme might be developed along the following lines. A government might pay some share (say, fifty per cent) of the full additional costs of meeting governmentally imposed pollution control standards. The capital cost would be the annual amortization of required anti-pollution capital investments, plus imputed interest. Operating costs would include the direct additional costs of energy, water, operating labor, and proper maintenance of the control effort. The calculated payment could be added to income for tax purposes.

Tax credits or cost sharing payments might be limited to the extent that annualized pollution control costs exceed some share (say, one per cent) of value added on a plant basis. The share of value added is used here as a proxy for burden, but it is not identical with burden.

A guiding rule of such an incentive system would be that pollution control costs must be defined as those incurred in meeting specific requirements imposed on the firm pursuant to government regulations. Government revenue officers could presumably determine the full additional annualized costs of pollution control on the basis of statements and other information provided by the affected firm.

\section{B. Award Payments}

Emission reduction payments could, theoretically, be geared to the amount of abatement achieved (i.e., pounds of pollutants recovered), or they could be geared to achieving and maintaining a particular standard of performance (i.e., a power plant reaching a ninety-five per cent reduction of potential sulfur oxide emissions). Payments could be adjusted to produce various levels of performance. For example, when weather forecasts indicate a severe temperature inversion which would trap pollution over a metropolitan area and create an air pollution episode, performance payments

\footnotetext{
${ }^{18} 1 d$. at 32 .

${ }^{11}$ Id.
} 
could be raised to reduce emissions and the resulting concentrations of air pollutants. Industries might respond by switching to low sulfur fuels or curtailing operations until the episode danger had passed. Award payments would help offset both the higher costs of fuel and the shutdown expenses.

While all of this is theoretically possible, a major problem with emission payments at the present time is that a technology for economically and effectively measuring emissions is not available. It is questionable, furthermore, whether engineering estimates of emission volumes would satisfy the measurement needs of an emission reduction payment system or of the legal requirements such a system might impose.

\section{Emission Fees}

With an emission fee system, a firm could choose to abate pollution to meet emission standards or pay a relatively high emission charge. An analogous system of effluent fees has been applied in the Rhine Valley for water pollution control with some success. Emission charges for air pollution control, however, appear less well suited to the pollution control problem.

In water pollution, it may make sense to give a large polluter like an industrial plant a choice between treating its own effluent or paying a fee for a government agency to do a job of stream cleaning from multiple sources. But the air cannot be stream-cleaned by such secondary off-site treatment systems. Once pollutants leave factory stacks or automobile exhausts they are in the air until dispersed by natural forces. As Allen V. Kneese has observed,

... we are in somewhat the same position in regard to polluted air as the fish are to polluted water. We live in it. Accordingly, control of air pollution is largely a matter of preventing pollutants from escaping from their sources, eliminating the source, or shifting location of the source or the recipient. ${ }^{15}$

In water, a polluter who decides to pay an effluent fee rather than control emissions at the source is, in essence, making a payment for a service-which cannot be rendered for polluters of air.

Another difficulty is that a fee system could be exceedingly difficult and costly to administer. As mentioned above, emission measurement technology is presently inadequate to meet the requirement that a regulatory agency be able to determine with some precision just how much an individual polluter is contributing to the atmospheric burden. It might be equally difficult to decide how to determine what the fee structure should be in order to attain a satisfactory level of air quality.

\section{IV}

\section{Regulation}

The obvious alternative to purely economic incentives would be to legislate emission standard regulations and enforce them with fines and other penalties. New

\footnotetext{
${ }^{10}$ Kneese, supra note 7 , at 33 .
} 
Jersey is one example of a state that has recently passed air pollution legislation that combines a system of regulations with fines for violations and rebates for compliance. The I967 amendment to the Air Pollution Control Act of 1954 provided that: ${ }^{16}$

Any person who violates the provisions of this act or any code, rule, regulation or order promulgated or issued pursuant to this act shall be liable to a penalty of not more than $\$ 2,500$ to be collected in a civil action by a summary proceeding under the penalty enforcement law (N.J.S. 2A:58-x et seq.) or in any case before a court of competent jurisdiction wherein injunctive relief has been requested. If the violation is of a continuing nature, each day during which it continues after the date given by which the violation must be eliminated in accordance with the order of the department, shall constitute an additional, separate and distinct offense.

The department is hereby authorized and empowered to compromise and settle any claim for a penalty under this section in such amount in the discretion of the department as may appear appropriate and equitable under all of the circumstances, including a rebate of any such penalty paid to the extent of $90 \%$ thereof where such person satisfies the department within I year or such other period as the department may deem reasonable that such violation has been eliminated or removed or that such order or injunction has been met or satisfied, as the case may be, by the installation of air pollution control apparatus.

In such a situation a polluter will try to find the least costly method of control (including methods that produce salable by-products). Process controls and fuel substitution will be used in many instances instead of heavy investment in control equipment.

Net costs of control may be passed on to consumers, equity holders, employees, or suppliers-a less direct but still effective sharing of costs. There may, of course, be instances where price increases result in customers substituting other products, or investors choosing among alternative investments if their returns are reduced by the added costs of pollution control.

Where a system of regulation is used, there should always be adequate provision for assisting companies particularly hard-hit by the cost of controls.

\section{$\mathrm{V}$}

\section{Present Trends}

Present trends in the United States indicate greater use of regulations than of direct cost-sharing incentives. In its report, the Working Committee on Economic Incentives stated: ${ }^{17}$

Across-the-board cost-sharing in the form of tax write-offs is not recommended because it distorts the tax structure, causes the total cost of pollution abatement to rise significantly, promotes excessive use of capital equipment and waste treatment facilities, and discourages selectivity in environmental quality management. Acrossthe-board use of grants and loans is similarly handicapped and, in addition, is subject to fluctuations in Congressional appropriations.

\footnotetext{
${ }^{16}$ Ch. 105, I, [I967] N.J. Laws (I967 N.J. Sess. Law Service 357).

${ }^{17}$ Federal Coordinating Comattree 5.
} 
Except for the control of automobile emissions, the establishment of regulations or other incentives is, however, a state and local responsibility. Both the Clean Air Act of 1963 and its subsequent amendments and the Air Quality Act of $1967^{18}$ encourage states to take this responsibility. Under the Clean Air Act, for instance, federal grants have helped to produce a substantial expansion of state and local control programs. Prior to passage of this act only sixteen states had air pollution control legislation; today the number is forty-six. In addition, federal abatement actions in a number of interstate areas have paved the way for state and local agencies to cooperate across territorial boundaries. The Clean Air Act also helped stimulate a much greater effort to develop new and improved control technology.

The Air Quality Act of 1967 reaffirms that state and local governments have a primary role in protecting air quality, ${ }^{19}$ but gives the federal government increased authority to act in emergency situations ${ }^{20}$ increased responsibility for reviewing and approving state and regional control programs, ${ }^{21}$ and finally, authority to establish federal controls in states or regions which fail to establish needed controls. ${ }^{22}$

Since air pollution is no respecter of geographical boundaries, the Air Quality Act is designed to deal with air pollution on a regional basis. The act requires the Department of Health, Education, and Welfare to designate specific air quality control regions. ${ }^{23}$ These regions will be designated on the basis of factors that suggest that a group of communities should be treated as a unit for the purpose of setting and implementing air quality standards. At the same time, the Department is required to develop and publish air quality criteria for a pollutant or group of pollutants, ${ }^{24}$ together with information on available control techniques applicable to the various sources of that pollutant or group of pollutants. ${ }^{25}$ Air quality criteria are derived from the best available scientific knowledge of the effects of air pollutants on health and welfare. Still another requirement is that the Department publish information on control techniques that will identify the best methods available for reducing pollutant emissions at their various sources and the costs thereof-whether these techniques involve the application of control equipment, changes in fuel use or industrial processes, or any other practical approach.

As soon as a criterion and the related information on control techniques is published for a pollutant, the act begins to have a direct effect on those states responsible for the air quality control regions that have been designated. The act sets up a timetable which states must follow in developing air quality standards and implementation plans for the designated regions. It is possible that the implementation plans will

\footnotetext{
${ }^{18}$ The earlier legislation has been replaced by the Air Quality Act of $x 967,8$ I Stat. 485 .

${ }^{20}$ See, e.g., $\delta$ I02(a), 8I Stat. 485 (I967); H.R. REP. No. 728, goth Cong., Ist Sess. I (I967).

${ }^{20}$ \& $108(\mathrm{k}), 8 \mathrm{r}$ Stat. 497 ( 1967$)$.

${ }^{21}$ See, e.g., $\$$ I08(c)(I), 8I Stat. 492 (I967).

${ }^{22} \$ 5 \mathrm{I0} 8(\mathrm{c})(2)-(4), 8 \mathrm{I}$ Stat. $492(1967)$.

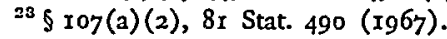

24 $\$ 107$ (b), 8I Stat. 49I (1967).

${ }^{35} \$ \mathrm{ro7}(\mathrm{c}), 8 \mathrm{I}$ Stat. $49 \mathrm{I}$ ( 1967$)$.
} 
offer financial incentives as well as regulations to encourage application of controls. If the Secretary of Health, Education, and Welfare finds that the air quality standards and plans for their implementation are consistent with criteria and related control technology information, then those standards and plans will take effect. ${ }^{2 b}$ If a state fails to establish standards, or if the Secretary finds that the standards are not consistent with the criteria, he can initiate action to insure that appropriate standards are set. ${ }^{27}$ States may request a public hearing on any standards developed by the Secretary; in such cases the hearing board's decision will be binding. ${ }^{28}$ States will be expected to assume the primary responsibility for application of the air quality standards. If a state's efforts prove inadequate, the Secretary is empowered to initiate abatement action. ${ }^{29}$

Backed by a federally-supported research and development effort enlisting the support of industry, ${ }^{30}$ and by federal grants for state and local control programs, the national drive to control air pollution should be considerably accelerated. There should be the concentration of interest, money, and talents that will allow us to lower the emission of pollutants which exact such high economic and social costs today and threaten to exact even higher costs tomorrow. While the major vehicle for this progress may continue to be the establishment of emission regulations, it is entirely possible that the development of improved instrumentation for measuring emissions will make other forms of incentives attractive.

\footnotetext{
${ }^{10}$ s $\mathrm{ro8}(\mathrm{c})(\mathrm{x}), 8 \mathrm{r}$ Stat. 492 (I967).

${ }^{97} 5 \mathrm{ro8}(\mathrm{c})(2), 8 x$ Stat 492 (1967).

${ }^{88}$ f $\mathrm{ro8}(\mathrm{c})$ (3), 81 Stat. 492 (x967).

${ }^{20} 5 \mathrm{ro8}(\mathrm{c})(4), 81$ Stat. 493 (1967).

${ }^{30}$ See $\$ \$ 103-04,8 \mathrm{x}$ Stat. 486 (1967).

81 § ro5, 8I Stat. 489 (1967).
} 